\title{
INTERCULTURAL APPROACH AND CHARACTER EDUCATION- BASED DEVELOPING ENGLISH TEXTBOOK
}

\author{
Titi Rokhayati \\ Purworejo Muhammadiyah University, Indonesia \\ Email: rokhayatititi@yahoo.com
}

\begin{abstract}
APA Citation: Rokhayati, T. (2016). Intercultural approach and character education- based developing English textbook. English Review: Journal of English Education, 5(1), 131-140
\end{abstract}

Received: 08-10-2016

Accepted: 07-11-2016

Published: 01-12-2016

\begin{abstract}
This research was conducted with the purpose to develop the materials of textbook based on intercultural approach and character education as a guideline in learning English for senior high school class $X$ in Purworejo regency, and to determine the validity of the development of textbooks. The method used in this research is R and D. Based on the findings, it can be concluded that English book published by the government in 2014 requires improvement in terms of 1 ) the current topic which are very important because the topics are most needed by the students as information directly from the book contained current trends, 2) Insight of diversity means that the knowledge, experience, and discourse reflected in the texts contained insight of diversity including the target language, and 3 ) Relationship with social emotional material students need to be improved. The material contained in this book will be developed based on the intercultural approach, meaning that based on the findings and goals to be achieved in this study, the findings of the field study is appropriate.

Keywords: Textbooks, English, intercultural approach, character education
\end{abstract}

\section{INTRODUCTION}

English is the first foreign language in Indonesia which becomes a compulsory subject for students of Junior high school to universities. In line with the development of globalization era, English is very important to be mastered since many people learn English for various intentions. They try to understand some English texts, for having interview, even for studying abroad, they need to master English either written or oral. Observing the importance of English in any sphere of life, the government must be able to change the paradigm of educational system in Indonesia.

The change of basic paradigm in the national education system happenned in 2009s, the minister of education wants to have a focus in the national education which is known as character education. The government has made character education as the priority program in the national development. The education which is based on culture and nation character is attached to the curriculum and sylabus, the teachers find it is difficult to understand the meaning of the characters. It must be applied in the lesson plan.

Character is someone's personality which is formed as the result of integration of understanding, the behaviour to the value, and the daily attitude. Character implies a standard of moral which involved a value consideration (Hurlock in Kesuma 2012). 
Character education is an education to form an individual's personality through the character education in which the result can be seen in the good attitude, honesty, responsibility, appreciate others' right, and work hard (Lickona in Gunawan, 2012) The characters' value intended is the personality or character which can be reached in teaching-learning process. There are some important things in teaching learning process. They are input, process and output. In the process of teaching learning, the teacher needs to use method and media. One of the important media is textbook.

Based on Direktorat Pendidikan Menengah Umum (in Muslich, 2010, p. 50) a "textbook is sekumpulan tulisan yang dibuat secara sistematis berisi tentang suatu materi pelajaran tertentu, yang disiapkan oleh pengarangnya dengan menggunakan acuan kurikulum yang berlaku." While Richards and Schmidt (2010) say that textbook is a book contained certain subject which is used to teach or study in school or universities.

English textbook has some special characteristics in which covers some limitations which relate to how to use the language, the function of the language, and condition of the society. The choice of materials and the appropriate technique can make the students interested. When the teacher finds some unappropriate materials which are not in line with the students' need, the teacher must develop the material to make it suited to the students' need. The teacher then has to select, adapt, and develop the materials. Actually a teacher must decide on the materials needed, students' activities, and the strategy he must apply in teaching learning process. The policy of teaching English must be in line with the availability of English textbook which fulfills students' need and the curriculum. Besides, the intercultural approach is needed to enrich the teachers' knowledge in English teaching learning.

The concept of "inter-cultural" is need to be conceived as independent of both their native culture and the new culture. While, the concept of teaching is helping someone to learn, guiding, providing with the knowledge, and giving instructions. Teaching intercultural is helping the students to understand their own culture and respect other cultures because in fact there is an influence from other cultures.

Soler (2007) claims that we are so familiar with our own culture that we do not even realize it is there and, inevitably, it influences our expectations when we establish contact with people belonging to a different culture.

Intercultural understanding is the ability to participate and negotiate with people in a variety of contexts.

Participating and negotiating with people requires an ability to know and understand 'your' culture, 'another's' culture and have skill in working between your own and another's culture. (http://www.asiaeducation.edu.au/for lecturers/professional_learning/intercul tural_competencies/developing_intercul tural_understanding/diu_resources/res ource_1_definitions.html).

An intercultural approach gives lecturers and learners a clearly defined and consistent set of purposes, while intercultural communication should be a clearly defined option in language education. The goals of any course should specify whether learners, lecturers and institutions are concerned with

(1) increasing language proficiency.

(2) gaining factual knowledge about the target culture. 
ENGLISH REVIEW: Journal of English Education Vol. 5, Issue 1, December 2016
ISSN 2301-7554

https://journal.uniku.ac.id/index.php/ERJEE
(3) acculturating, and/or.

(4) mediating between cultures (Corbett, 2003).

Intercultural competence is a set of cognitive, affective, and behavioral skills and characteristics that support effective and appropriate interaction in a variety of cultural context (Bennet, 2011). In addition, Fantini (2006, p. 12) defines intercultural as "a complex of abilities needed to perform effectively and appropriately when interacting with others who are linguistically and culturally different from oneself."

The most elaborated model of intercultural competence is the model of savoirs developed by Byram and Zarate (1994): (1) savoir, (2) savoir être, (3) savoir comprendre, and (4) savoir apprendre.

1) Savoir refers to knowledge of self and others, of their products and practices and the general processes of interaction. This constitutes a body of knowledge on which other operations can be performed.

2) savoir être, which involves an attitudinal disposition towards intercultural engagement manifested in approaching intercultural learning with curiosity, openness, and reflexivity.

3) Savoir comprendre, which involves learning how to interpret and explain cultural practices or documents and to compare them with aspects of one's own culture.

4) Savoir apprendre, which is the ability to make discoveries through personal involvement in social interaction. Byram (1997) adds a further dimension, savoir s'engager, which refers to the ability to make informed critical evaluation of aspects of one's own and other cultures. In terms of character education, there are 9 pillars which will be developed (UU no 20 tahun 2003 pasal 3), they are; 1) love God and the creature, 2) responsibility, discipline, and independence, 3) honesty and wisdom, 4) respect and polite, 5) charity and cooperation, 6) self-esteem, creative and hard-work, 7) leadership and justice, 8) kindness and humble, and 9) tolerance, peaceful, and unity. Another Pillars in the characters education are: 1 ) religious, 2) honest, 3) tolerance, 4) discipline, 5) hard-work, 6) Creative, 7) independence, 8) democratic, 9) curiosity, 10) nationality, 11) patriotism, 12) appreciative, 13) friendliness, 14) peaceful, 15) love reading, 16) environment concern, 17) social concern, and 18) responsibility.

In this research the researcher has a research question; How is the development of the textbook based on intercultural approach and character education as the guidance book of English teaching learning for Class $\mathrm{X}$ semester 1 in Purworejo Regency?

\section{METHOD}

This research uses $\mathrm{R}$ and $\mathrm{D}$ Method developed by Richey (2007). Based on the objectives of the research, this research belongs to the research and development method. Sugiyono adds that "research and development is a research method which is used to produce a particular product, and test the effectiveness of product" (2012, p. 407). Richey and Klein (2007) call it developmental or development research, which then name it design and development research. It is divided into 3 steps; exploring (research), developing (design and development), and evaluation (design research). This research analyzes the exploring stage and the developing stage is still on the process. So, the researcher only discuss on the exploring or preliminary study. The subjects of the research are the tenth grader of SMAN 5 and SMAN 7 in 
Purworejo Regency. There are 160 students and 5 teachers. The main instrument is the researcher herself and the supporting instrument is questionnaire and observation for students and for teachers. The research was conducted seven times for collecting data for students and teachers on April to July 2016.

\section{RESULTS}

In a preliminary study, the researcher did a step namely literature study. The literature study is a step in which the researcher collected various books and sources which are relevant to the topics discussed. The books were very helpful as the basic resource of theories, so in discussing the topic the researcher can give clear and focused discussion.

After doing some research, the researcher presented a field study on textbooks used. The Textbook analyzed was an English textbook for the first semester of class $X$ in SMAN 5 and SMAN 7 Purworejo. The book was published by Kemendikbud 2014. The research findings will be described as follows:

The results of the students' Questionnaire In this section the researcher presents the results of questionnaire given to the students in grade X SMAN 5 and SMA N 7 Purworejo.

Table 1. The subjects of the research

\begin{tabular}{|c|c|c|}
\hline SMA & Science class & Social class \\
\hline SMAN 5 & 32 & 64 \\
\hline SMAN 7 & 32 & 32 \\
\hline SUM & 64 & 96 \\
\hline TOTAL & \multicolumn{2}{|c|}{160} \\
\hline
\end{tabular}

The subjects are the students of SMAN 5 and SMAN 7. They are at the tenth grade semester 1 . The schools are state senior high school. Those schools are included as favorite schools in Purworejo. Both schools implement 2013 curriculum. The researcher chose 64 students majoring in science and the social class were 96 students.

Table 2. The result of students' questionnaire

\begin{tabular}{llccccc}
\hline No & \multicolumn{1}{c}{ The questions } & No of & \multicolumn{2}{c}{ Agree } & \multicolumn{2}{c}{ Disagree } \\
\cline { 5 - 7 } & & item & Number & Percentage & Number & Percentage \\
\hline 1. & $\begin{array}{l}\text { The conformity between the } \\
\text { content and the core competencies }\end{array}$ & 1 & 143 & 95.33 & 7 & 4.67 \\
\hline 2. & $\begin{array}{l}\text { The materials represent social } \\
\text { function }\end{array}$ & 2 & 125 & 84.46 & 23 & 15.54 \\
\hline 3. & $\begin{array}{l}\text { The aspects and meaning } \\
\text { structure described clearly }\end{array}$ & 3 & 111 & 75.00 & 37 & 25.00 \\
\hline 4. & Linguistic feature is well-defined & 4 & 110 & 73.33 & 40 & 26.67 \\
\hline 5. & $\begin{array}{l}\text { The topics in the materials are } \\
\text { trend topics }\end{array}$ & 5 & 47 & 31.76 & 101 & 68.24 \\
\hline 6. & $\begin{array}{l}\text { The materials include developing } \\
\text { life skills }\end{array}$ & 6 & 98 & 68.06 & 46 & 31.94 \\
\hline 7. & $\begin{array}{l}\text { the insight of diversity is well- } \\
\text { described }\end{array}$ & 7 & 78 & 51.66 & 73 & 48.34 \\
\hline 8. & The materials are suited to the & 8 & 137 & 82.33 & 29 & 17.47 \\
\hline
\end{tabular}




\begin{tabular}{|c|c|c|c|c|c|c|}
\hline & $\begin{array}{l}\text { development level of students' } \\
\text { cognitive }\end{array}$ & & & & & \\
\hline 9. & $\begin{array}{l}\text { The materials are suited to the } \\
\text { students' social emotional level }\end{array}$ & 9 & 82 & 56.55 & 63 & 43.45 \\
\hline 10. & $\begin{array}{l}\text { The message in the material is } \\
\text { clearly-read }\end{array}$ & 10 & 103 & 69.13 & 46 & 30.87 \\
\hline 11. & Use appropriate language & 11 & 137 & 92.57 & 11 & 7.43 \\
\hline 12. & Good management of chapters & 12 & 122 & 81.88 & 27 & 18.12 \\
\hline 13. & $\begin{array}{l}\text { Interconnectedness of chapters } \\
\text { and sub chapters }\end{array}$ & 13 & 129 & 87.76 & 18 & 12.24 \\
\hline 14 & $\begin{array}{l}\text { Good performance in presenting } \\
\text { the materials }\end{array}$ & 14 & 133 & 89.26 & 16 & 10.47 \\
\hline 15. & $\begin{array}{l}\text { The contents of the chapters are in } \\
\text { balance }\end{array}$ & 15 & 137 & 93.20 & 10 & 6.80 \\
\hline 16. & The focus is the students' need & 16 & 105 & 70.47 & 44 & 29.53 \\
\hline 17. & $\begin{array}{l}\text { The materials lead the students' } \\
\text { idea, creativity and critical } \\
\text { thinking }\end{array}$ & 17 & 115 & 77.18 & 34 & 22.82 \\
\hline 18. & $\begin{array}{l}\text { The materials enable the students } \\
\text { to learn }\end{array}$ & 18 & 96 & 64.43 & 53 & 35.57 \\
\hline 19. & $\begin{array}{l}\text { The materials enable the students } \\
\text { to have self evaluation }\end{array}$ & 19 & 99 & 66.4 & 50 & 33.56 \\
\hline 20. & $\begin{array}{l}\text { There are introduction, content } \\
\text { and closing }\end{array}$ & 20 & 127 & 86.39 & 20 & 13.61 \\
\hline & Total number & & 2234 & 74.92 & 748 & 25.08 \\
\hline
\end{tabular}

Based on the table above, it can be drawn that the questions in the questionnaire about the instrument ratings book filled out by the students by answering agree and disagree more dominant on the answers agree. However, if we look thoroughly, there are three questions that are more likely to provide input into the development of the material that is about current topics, they agree to answer a number of 47 (31.76\%) and disagree 101 (68.24\%). Then, the second of the insights of diversity in the material, those who answered agree is $78(51.66 \%)$ and disagree is 73 ( $48.34 \%)$ it was almost equal. The third on a question about the content of the material is in conformity with the social emotional development of students who answered agree is 82 $(56.55 \%)$ and disagree is $65(43.45 \%)$.

Seeing the first question, namely number of items 5 (topics contained in the materials are current topics), it is clear that the students who answer disagree are bigger than who answered agree. The second question i.e. number of items 7 (Development of insights diversity is already imprinted in the material), insight into the diversity in this case includes not only insight into the cultures that exist in Indonesia but also the cultures of the target language that is English. So, this insight also includes students' horizons about English culture as the target language. The answer of agree and disagree was no significant difference, it was almost the same. The third question, number of items 9 (Fill material according to the social emotional level of the students) students who agree is more than those who was disagree but the difference was only $3.10 \%$.

Based on the findings of the students' questionnaire, it can be concluded that the English book for tenth grade semester 1 published by the government in 2014 requires an improvement in the current topic, insight into the diversity, 
and about the relationship of social emotional material with students. Current topics are very important because the topics are most needed by students as the information directly from the book what are the current trends. It is considered very important for the students so that the students get inspiration from books and then interpret it in the form of tasks by the teacher.

Insights of diversity means that the knowledge, experience, and discourse reflected in the texts contained in the book because the English books here related to diversity also on the diversity of the target language. In accordance with the title of this study that the material contained in this book will be developed based on the intercultural approach, meaning that based on the findings and goals to be achieved in this study, the findings of the field study is appropriate.

Linkages of material with students' social emotional which need to be improved. It may also be associated with the development of educational materials based on the character suited to the problems raised in this research.

The results of the teachers' questionnaire

Teachers' questionnaires are filled out by five teachers who teach in the tenth grade science and social studies. The three teachers are from SMAN 7, they are Dr. Nikmah Nurbaity, M.Pd., Agus Setiyono, M.Pd., and Drs. Moersito. Meanwhile, while the other two teachers came from SMAN 5 namely Heru, M.Pd., and Bambang, M.Pd.

The results of the questionnaire can be described as follows:

Feasibility contents:

1) Core competencies and basic competencies are implied
The core competencies and basic competencies should be written clearly, so it can be seen from the text and the real competencies that can be reached.

2) Social functions has not yet written The social function especially from the text are found implicitly. In part of speaking, it must be practice so the students can make use of the text in the daily life.

3) It needs updating The novelty of the topics are so important for the students to be up to date, because it will make students update the newest thing in the world.

Feasibility of Language

1) The material is already relevant to the students' need

The various topics in the textbook has fulfilled the students' need. It covers some topics which are in line with what students want, the weakness is on the novelty although the topic has been reached the students' need but it still needs to be reviewed on the topics which have trends nowadays.

2) Communication message is understood

The communication message is understood means that the packages of messages are understood well. The students understand well as the use of the language is simple and not complicated.

3) It meets the elements of coherence and cohesion

The coherence and cohesion of the text is appropriate. They meet the elements.

Eligibility of the Presentation

1) Presentation system has been coherent and balanced It has good presentation, easy to understand and interesting. 
2) Lack of critical thinking skills The points of critical thinking skill need to be improved because it is very useful for the students to have some interesting topics which lead them to think critically.

3) Presentation of introduction, contents, and closing are complete The book's performance has been complete. It has introduction, contents and closing.

From the summary of the teachers' questionnaire described above, it can be seen that the contents of the feasibility of the contents are adequate but core competencies and basic competencies are still implied while for social functions has not been written completely. From the side of the topic shows that the topic still needs updating means that the topic should be adjusted to the current circumstances.

In terms of the feasibility of the language, it is proved that the material was relevant to learners. Communication message has been understood and already meet the elements of coherence and cohesion. This indicates that the English books for Class $X$ the first semester is deserved to be used.

In terms of the presentation, there are some opinions from the teachers as the respondents of the research, they argue that the system presentation is coherent and balanced, it has not yet presented skills of critical thinking and the presentation in terms of introduction, contents and closing is complete.

Briefly, it can be described that from the questionnaire evaluation the feasibility of the contents are adequate but the core competencies and basic competencies are still implied while social function is not completely written. From the side of the topic it shows that the topic still needs updating means that the topic should be adjusted to the current circumstances. In terms of feasibility of language it is proved that the material was relevant to learners," communication message has been understood and already meet the elements of coherence and cohesion. This indicates that the English books for Class $X$ 1st semester is deserved to be used. In terms of presentation of the opinion there are some teachers as respondents said that the system of presentation is already coherent and balanced, but it has lack of critical thinking skills and in terms of the presentation the introduction, contents and closing is complete.

\section{The Result of Observation}

One of the illustrations of teaching learning process is described here. The teacher and the students were enjoying the English class. It seems that they can make use of the textbook well. The teacher asked the students about the reading text, but he started the teaching by giving description about a unique place which he ever visited. Using vocabularies which can be understood well the students enjoyed the teacher's story. In the description, the teacher just described about the place, the location, and the visitors of the place, the description about what is the place for, the culture surrounding the place, and the people's habit in the place were not described yet. Seeing that the background of the place was important part in describing place it must be described also.

Thus, from the observation of teaching and learning process, it should be improved. Some teachers like to have their own ways of teaching by describing something that they have ever seen. It is good because the description became so real for the students since it is based on the experience, but some parts may miss 
in the description as the teacher enjoyed much the explanation. Besides, there are also some characters building found in the text but they do not describe explicitly so the readers must infer them through the text.

\section{CONCLUSION}

The English book published by the government in 2014 requires improvements in terms of Current topics, insights about the relevance of diversity, and the relationship of material and students' social emotional.

Current topics are very important because the topics are most needed by students as the information directly from the book what are the current trends. It is considered very important for the students so that the students get inspiration from books and then interpret it in the form of tasks by the teacher.

Insights of diversity means that the knowledge, experience, and discourse reflected in the texts contained in the book because the English books here related to diversity also on the diversity of the target language. It is explicitly described in the book how to congratulate others for example in which the culture of the target language is being learned but it also includes the culture of Indonesian in which something about 'Selamatan' is also learned. In accordance with the title of this study that the material contained in this book will be developed based on the intercultural approach, meaning that based on the findings and goals to be achieved in this study, the findings of the field study is appropriate.

Linkages of the material with students' social emotional need to be improved. It may also be associated with the development of educational materials based on the character which is suitable to the problems raised in this research.

Current topics, insight of diversity, and linkages of material with students' social emotional are the three points which are improved in this research. By developing the material it is hoped that the textbook is more acceptable for the students.

The observation has described about the students and teacher's activity but the description needs to be improved. It relates to some important points about the place described. The teacher should also described about the people who live in the surrounding so the students know well about the life of the surrounding society which may also be influenced by the existence of the place.

\section{ACKNOWLEDGEMENT}

In the name of Allah, the beneficient and the merciful, praise belong to Allah "Lord of Universe" who has given us inspiration, so that the researcher can finish this part of the study successfully. This study is to fulfill the task of lecturers as a researcher who must always have research every year and publish the research but this research is only a part of the whole research in $\mathrm{R}$ and $\mathrm{D}$ research.

The researcher would like to express her greatest gratitude to several people who participated in finishing this study. She extends her sincere gratitude and appreciations to:

1. Drs. Supriyono, M.Pd as the rector of Purworejo Muhammadiyah University.

2. Yuli Widiyono, M. Pd. as the dean of the teacher training and Educational Sciences Faculty.

3. Abdul Ngafif, M.Pd. B.I. as the colleague who helps the researcher in doing the research study. 
4. The English teachers of SMAN 5 and SMAN 7 Purworejo for the good help and cooperation.

5. The students of Class X SMAN 5 and SMAN 7 Purworejo, thanks for good cooperation and collaboration.

6. All of my colleagues in English Education Program of Purworejo Muhammadiyah University.

7. All of my friends in UMJ who always motivate me to be a better person in the eye of family and of GOD. Love you sist!

8. My big family, my beloved husband who always be with me in happiness and sadness, my children who love me so much days and night, and my brothers. Thanks for the support, prayers, motivations, love, and cares.

\section{REFERENCES}

Bennett, M. J. (2012). Developing Intercultural Competence for International Education Faculty and Staff. AIEA CONFERENCE * FEBRUARY 20-23,2011 SAN

FRANCISCO, CA, USA. Association of International Education

Administrators, www.aieaworld.org

Byram, M., \& Zarate, G. (1997). Defining and assessing intercultural competence: Some principles and proposals for the European context. Language Teaching, 29, pp. 14-18.
Corbett, J. (2003). An intercultural approach to English language teaching. Clevedon: Cromwell Press Ltd.

Fantini, A. E. (2006). Exploring and assessing intercultural competence. Retrieved October 1, 20015, from http://www.sit.edu/publications/do cs/feil_research_report.pdf

Gunawan, H. (2012). Pendidikan karakter: Konsep dan implementasi. Bandung: Alfabeta.

Kesuma, dkk. (2012). Pendidikan karakter: Kajian teori dan praktik di sekolah. Bandung: Remaja Rosdakarya.

Muslich, M. (2009). KTSP (Kurikulum Tingkat Satuan Pendidikan): Dasar pemahaman dan pengembangan. Jakarta: PT. Bumi Aksara

Richards, J. C., \& Richard S. (2010). Longman: Dictionary of language teaching $\mathcal{E}$ applied linguistics (4th ed.). Malaysia: Pearson Education Limited

Richey, R. C., \& Klein, J. D. Design and development research: method, strategies, and issues. New York: Routledge.

Soler, E. A., \& Jorda, M. P. S. (2007). Intercultural language use and language learning. Dordrecht: Springer.

Sugiyono. (2012). Metode penelitian pendidikan: Pendekatan kuantitatif, kualitatif, dan $R \mathcal{E D}$. Bandung: Alfabeta

(http:/ / www.asiaeducation.edu.au/for_lect urers/professional_learning/intercult ural_competencies/developing_interc ultural_understanding/diu_resources Lresource_1_definitions.html). 


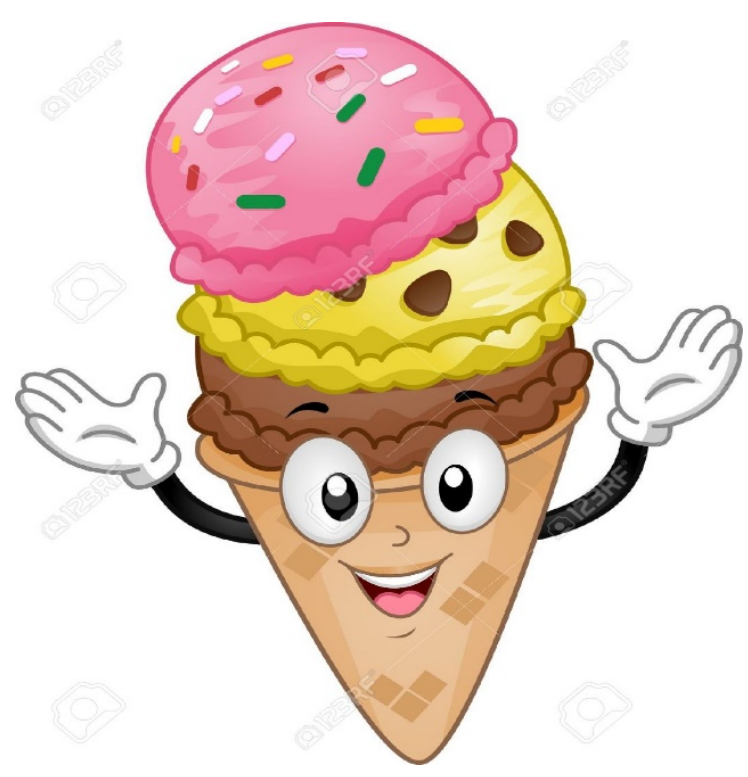

Ice cream

There was an elderly couple who in their old age noticed that they were getting a lot more forgetful, so they decided to go to the doctor. The doctor told them that they should start writing things down so they don't forget. They went home and the old lady told her husband to get her a bowl of ice cream. "You might want to write it down," she said. The husband said, "No, I can remember that you want a bowl of ice cream." She then told her husband she wanted a bowl of ice cream with whipped cream. "Write it down," she told him, and again he said, "No, no, I can remember: you want a bowl of ice cream with whipped cream." Then the old lady said she wants a bowl of ice cream with whipped cream and a cherry on top. "Write it down," she told her husband and again he said, "No, I got it. You want a bowl of ice cream with whipped cream and a cherry on top." So he goes to get the ice cream and spends an unusually long time in the kitchen, over 30 minutes. He comes out to his wife and hands her a plate of eggs and bacon. The old wife stares at the plate for a moment, then looks at her husband and asks, "Where's the toast?"

(Source: http://www.study-express.ru/humour/funny-stories.shtml, picture: www.google.co.id) 